Social Policy \& Society 1:2, 169 Printed in the United Kingdom

(C) 2002 Cambridge University Press DOI:10.1017/S1474746402002105

\title{
Guide to Some Sources
}

\section{Bill Jordan (with Tony Maltby)}

Professor of Social Policy, Universities of Exeter and Huddersfield

Reader in Social Policy University of North London

G.M.Watson@exeter.ac.uk

The theme of social policy in Central Europe is not widely documented in the Englishlanguage journals, with the exceptions of the Journal of European Social Policy and International Social Security Review, although Global Social Policy and Social Quality can now be added to this ever-increasing list.

The following websites contain valuable information and commentary:

Europa, the Official European Union website (http://europa.eu.int) contains a wealth of information on all matters relating to the European Union and is presented in the languages of the Union. It has links to other important and related websites such as European Governments on line at the following address

(http://europa.eu.int/abc/governments/).

Euroguide Provides access to internet resources about the European Union including links to many EU documents and directives. Sites are listed alphabetically by category.

European Access Plus (http://www.europeanaccess.co.uk/) is an online information service that provides a guide to the mountain of European Union information. It allows location of up to date information on issues, people and policies of the EU and wider Europe.

REESweb (http://www.ucis.pitt.edu/reesweb/ Provides links to resources for the interdisciplinary study of Russia and Eastern Europe.

Centre for Russian and East European Studies (CREES) (http://www.bham.ac.uk/crees/). This is based at the University of Birmingham, UK and part of the European Research Institute. It contains a large selection of links organised by subject matter. It also contains a large selection of web based newspapers from the various countries. This is an excellent resource for researchers with an interest in all aspects of Central and East European policy.

Center for East European Studies Copenhagen Business School

(http://www.econ.cbs.dk/institutes/cees/links/__links.html) This site contains a number of very useful links, and is well worth a look. 